\title{
A Chromatography based interaction analysis of two important biomolecules: neurotoxic Amyloid beta oligomers and human blood plasma proteins
}

\author{
Anuj Kumer Das ${ }^{1,2 *}$ \\ ${ }^{1}$ Swedish University of Agricultural Sciences (SLU), Uppsala-750 07, Sweden. ${ }^{2}$ Department of Biotechnology and Genetic Engineering, \\ University of Development Alternative (UODA), Dhaka-1209, Bangladesh.
}

\section{ARTICLE INFO}

Article history:

Received on: 01/09/2015

Revised on: 26/09/2015

Accepted on: $11 / 10 / 2015$

Available online: 22/10/2015

Key words:

Size exclusion

chromatography, molecular

interaction, Amyloid beta

oligomers, human blood

plasma proteins.

\begin{abstract}
A Size exclusion Chromatographic analysis was carried out to study the co-elution pattern as well as the molecular interaction between neurotoxic Amyloid beta oligomers and human blood plasma proteins. Four different types of Chromatographic columns like Sephacryl S-100 HR, Superose 12HR 10/30, Superdex 75 HR 10/300 and Superdex 200 HR10/300 used for analysis and among these columns, Superdex 200 HR 10/300 shown to be the most convenient column with better resolution where $20 \mathrm{mM}$ sodium phosphate, $\mathrm{pH} 7.4 ; 150$ $\mathrm{mM}$ sodium chloride proved as best working buffer at $0.5 \mathrm{ml} / \mathrm{min}$ flow rate. Co-elution study of mixture of amyloid $\beta$ oligomers and human plasma serum showed weak molecular interactions with blood plasma proteins but no strong interaction could be observed.
\end{abstract}

\section{INTRODUCTION}

Alzheimer's disease (AD) is an age-related progressive degenerative disorder which leads to progressive cognitive decline and subsequent death. Several studies have proved that the amyloid- $\beta$ (A $\beta)$ peptide, which is derived from the $A \beta$ precursor protein (APP), is responsible for $\mathrm{AD}[1-3]$ and is supported by hundreds of studies over the past two decades [411]. After synthesis from APP, A $\beta$ spontaneously aggregates into $\beta$-sheet rich fibrils, resembling those in plaques. $A \beta$ is soluble in its monomeric and oligomeric states but can aggregate into fibrils and deposit as extracellular plaques in the brain parenchyma. Surprisingly, the mechanism by which $A \beta$ causes neurodegeneration is still unclear [12]. Blood serum is a complex body fluid contains various proteins that range in concentration over at least 9 orders of magnitude. Plasma derived serum contains $60-80 \mathrm{mg}$ of protein $/ \mathrm{ml}$ in addition to various small molecules including salts, lipids, amino acids, and sugars [13].

\footnotetext{
* Corresponding Author

Email: akd_bt@yahoo.com
}

Serum contains several major proteins like albumin, immunoglobulins, transferrin, haptoglobin, and lipoproteins [13, 14]. Serum also contains many other proteins synthesized and secreted or lost from cells and tissues throughout the body $[15,16]$. Including most of very low relative abundances, about 10,000 proteins may be present in serum [17]. There have several techniques have developed for the quantitative assessment of the aggregation, including dimers and multimers, of the active protein but Size exclusion Chromatography is predominantly favored for routine and validated analyses because of both its speed and reproducibility. As one of the very important issues in biomedical research is to find out any biomarker to identify the disease in early stage and human serum is the most important specimen to detect the biomarker $[18,19,20,21]$. Since serum is easily available so, the biomarkers that are found in serum can be used to diagnostic tests and is target for therapeutic inventions. Currently no drugs are approved that prevents or slow the progression of $\mathrm{AD}$. The development of effective $\mathrm{AD}$ therapeutics is clearly a tremendous medical challenge. The molecular structure of its fibrils and pre-fibrillar oligomers is crucial for elucidating the aggregation 
pathway involved in plaque formation and for developing therapeutic and diagnostic agents. The aim of this study was to study the elution pattern of both $\mathrm{A} \beta$ oligomers and blood plasma proteins according to the size and to find out the $A \beta$ binding proteins from blood plasma which is very important for therapeutic studies against AD.

\section{METHODS AND MATERIALS}

All of the experimental parameters of size exclusion chromatography were considered step by step in this study.

\subsection{Columns used for Chromatographic analysis}

Four types of columns used in this study : Sephacryl S100 HR (GE Healthcare), Superose 12HR 10/30(GE Healthcare), Superdex 200HR and Superdex 75 HR (GE Healthcare).

\subsection{Optimization of the running conditions \\ 2.2.1 Buffer Selection}

Three different buffer compositions: $20 \mathrm{mM} \mathrm{Na}$ phosphate $\mathrm{pH} 7.4 ; 50 \mathrm{mM} \mathrm{NaCl}, 20 \mathrm{mM}$ Na-phosphate $\mathrm{pH}$ 7.4; $100 \mathrm{mM} \mathrm{NaCl}$ and $20 \mathrm{mM}$ Na-phosphate $\mathrm{pH} \mathrm{7.4;150} \mathrm{mM} \mathrm{NaCl}$ were tested for chromatographic analysis of $\mathrm{A} \beta$ oligomers and blood serum proteins. All of the chemicals and water used in this study were molecular biology grade.

\subsubsection{Resolution}

The resolution (Rs) between two peaks in a chromatogram is presented by,

$$
\begin{gathered}
\mathrm{Rs}=2 \Delta \mathrm{Z} / \mathrm{W}_{\mathrm{A}}+\mathrm{W}_{\mathrm{B}} \\
=2\left[\left(\mathrm{t}_{\mathrm{R}}\right)_{\mathrm{A}^{-}}\left(\mathrm{t}_{\mathrm{R}}\right)_{\mathrm{B}}\right] / \mathrm{W}_{\mathrm{A}}+\mathrm{W}_{\mathrm{B}} ;
\end{gathered}
$$

Where, the separation between peaks $\mathrm{A}$ and $\mathrm{B}$ is indicated by $\Delta \mathrm{Z}$ and $\mathrm{W}_{\mathrm{A}}$ and $\mathrm{W}_{\mathrm{B}}$ are the width at the base of peaks $\mathrm{A}$ and $\mathrm{B}$ respectively. Acceptable resolution is on the order of $\mathrm{Rs}=1.0$ and baseline between two peaks requires Rs>1.5.Resolution was calculated after careful analysis of the elution pattern of both of the samples.

\subsubsection{Flow rates}

Different flow rates started from $0.1 \mathrm{ml} / \mathrm{min}, 0.2 \mathrm{ml} / \mathrm{min}$, $0.3 \mathrm{ml} / \mathrm{min}, 0.4 \mathrm{ml} / \mathrm{min}$ and $0.5 \mathrm{ml} / \mathrm{min}$ were appliedand the resolution of the separation was observed. After optimizing the Conditions $50 \mu \mathrm{l}$ of $\mathrm{A} \beta$ oligomeric solution and $25 \mu \mathrm{l}$ of blood serum were loaded in column to observe the effect of flow rates inelution pattern.

\subsubsection{Aß oligomer and blood serum}

$\mathrm{A} \beta 42 \mathrm{CC}$ was co-expressed withZA $\beta 3$ Affibodyin Escherichia coli origami $B$ cells [22]. A $\beta$ oligomers were purified after several purification steps of Immobilized metal ion affinity Chromatography (IMAC), Size exclusion Chromatography(SEC), denatured IMAC and dialyzed overnight against $20 \mathrm{mM}$ sodium phosphate $\mathrm{pH} 7.2 ; 50 \mathrm{mMNaCl}$ with $5 \mathrm{mM}$ EDTA. A $\beta$ oligomers formed spontaneously during dialysis against sodium phosphate at pH 7.2. The blood serum (normal human serum, single donor) used in this experiment was purchased from $3 \mathrm{H}$ biochemical $\mathrm{AB}$, Uppsala, Sweden.

\subsection{Interaction study between $\mathrm{A} \beta$ oligomers and human blood serum proteins}

Mixtures of different ratios of $\mathrm{A} \beta$ oligomers and human blood serum proteins containing fractions (in $1: 1 ; 2: 1 ; 3: 1$ ratios respectively) were loaded on column toobserve the co-elution pattern and molecular interactions between the molecules. Fractions of Blood serum proteins was mixed with $\mathrm{A} \beta$ oligomers in ratios of $1: 1,1: 2$, and $1: 3$ which is followed by the loading of 50 $\mu 1$ mix on Superdex $200 \mathrm{HR}$ 10/300 equilibrated with $20 \mathrm{mM} \mathrm{Na}$ phosphate; $\mathrm{pH} 7.4 ; 150 \mathrm{mM} \mathrm{NaCl}$. Several optimized conditions like prior loading incubation on ice for different time durations, different concentrations, sample volumes also studied. After elution, the blood serum protein containing fractions were pulled together and concentrated for further interaction study with the concentrated fractions using the same ratios of $A \beta$ oligomers and human blood serum proteins containing concentrated fractions (1:1; $2: 1 ; 3: 1$ respectively). The eluted fractions from both of the experiments were analyzed by SDS-PAGE which is followed bysilver staining [23].

\section{RESULTS AND DISCUSSION}

After IMAC fractions containing $A \beta-Z A \beta 3$ were collected and concentrated up to $3.967 \mathrm{AU}$ at $280 \mathrm{~nm}$. A $\beta-Z A \beta 3$ containing fractions were concentrated up to $4.502 \mathrm{AU}$ at $280 \mathrm{~nm}$ after SEC also and finally separated from ZA $\beta 3$ after denature IMAC. A $\beta$ containing fractions were confirmed by SDS-PAGE. In SDS-PAGE image (Fig.1) it was observed single bands of about $6.2 \mathrm{kDa}$ which indicates that those fractions contained $\mathrm{A} \beta$ oligomers. Those fractions were concentrated using $3 \mathrm{kDa}$ cut-off to a final concentration of OD 280=1.3-1.8 AU. The sample was dialyzed against $20 \mathrm{mM}$ sodium phosphate $\mathrm{pH} 7.2 ; 50 \mathrm{mM} \mathrm{NaCl}$ with $5 \mathrm{mM}$ EDTA. A $\beta$ oligomers $(0.49 \mathrm{mM})$ formed spontaneously during dialysis against sodium phosphate at $\mathrm{pH}$ 7.2.

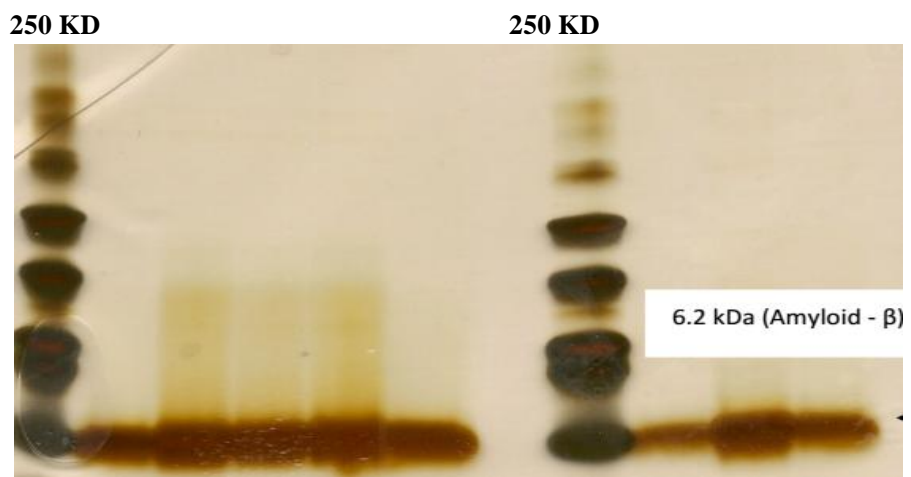

Fig.1: SDS-PAGE of corresponding A $\beta$ oligomeric fractions prior dialysis.

\subsection{Buffer composition, resolution and flow rate}

Among of different buffer compositions $20 \mathrm{mM}$ sodiumphosphate; pH7.4; $150 \mathrm{mM}$ sodium chloride showed better separation of both of the molecules. Sephacryl S-100 showed Rs 
value 1.76, Superose 12 showed Rs value 1.33, Superdex $75 \mathrm{HR}$ 10/300 showed Rs value 0.95 and Superdex 200 HR 10/300 showed Rs value 4.26 (fig.2). Acceptable resolution is on the order of $\mathrm{Rs}=1.0$ and baseline between two peaks requires Rs $>1.5$. So, it was observed that Superdex 200 HR 10/300 showed the best resolution than other tested columns. Different flow rates starting from $0.1 \mathrm{ml} / \mathrm{min}, 0.2 \mathrm{ml} / \mathrm{min}, 0.3 \mathrm{ml} / \mathrm{min}, 0.4 \mathrm{ml} / \mathrm{min}, 0.5 \mathrm{ml} / \mathrm{min}$ were applied using Superdex $200 \mathrm{HR} 10 / 300$ using $20 \mathrm{mM}$ Sodium-Phosphate; $150 \mathrm{mM}$ sodium chloride; $\mathrm{pH} 7.4$ as running buffer with both of $\mathrm{A} \beta$ and Blood serum and found Rs value 2.54, $2.39,2.19,3.44$ and 4.26 respectively. Among all of the flow rates $0.5 \mathrm{ml} / \mathrm{min}$ showed the best resolution (4.26) of separation.

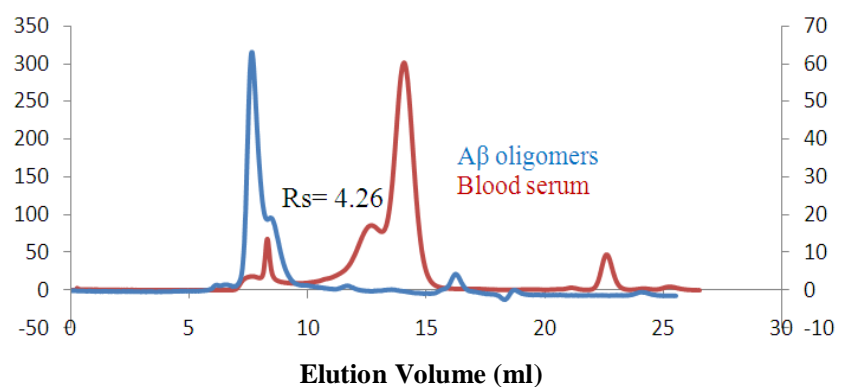

Fig.2: Size exclusion chromatogram of $A \beta$ oligomers and Blood serum at 280 nm in Superdex 200 HR 10/30. Superdex 200 HR 10/30 GL showed Rs value 4.26 at $0.5 \mathrm{ml} / \mathrm{min}$ flow rate.

\subsection{Interaction study of $A \beta$ oligomers with blood serum}

Laterin this experiment co-elution study of $A \beta$ oligomers and blood serum proteins was conducted to study any molecular interactions.

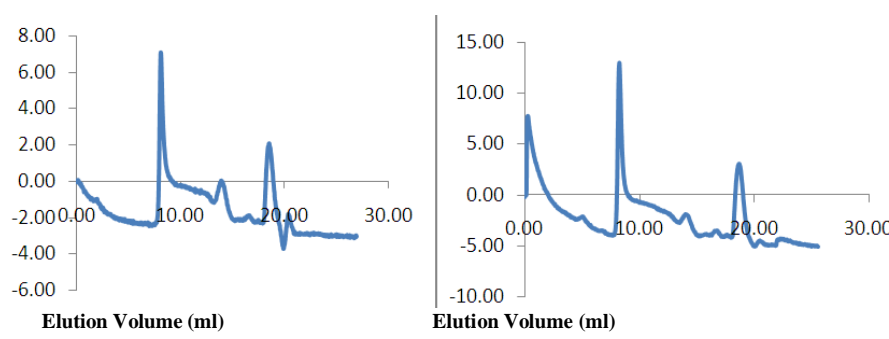

Fig.3: (a) Gel filtration chromatogram of $\mathrm{A} \beta$ oligomers and blood serum fractions (not concentrated) (1:1). A $\beta$ oligomeric fractions were started to elute at $7.98 \mathrm{ml}$ and ends to elute at $12.33 \mathrm{ml}$ of elution volume. (b) Gel filtration chromatogram of $\mathrm{A} \beta$ oligomers and blood serum fractions (not concentrated) $(1: 2)$. A $\beta$ Oligomeric fractions were started to elute after passing $7.41 \mathrm{ml}$ and ends at $12.78 \mathrm{ml}$ of elution volume. The corresponding fractions were analyzed by SDS-PAGE.

Fig. 3(a) and 3 (b) shows the chromatographic elution pattern of mixture of fractions of Blood serum proteins and $A \beta$ oligomers. In both of the chromatograms the first peak indicates the $A \beta$ oligomers which elute at around $7.98 \mathrm{ml}$ of elution volume and later at around $19 \mathrm{ml}$ of elution volume blood plasma proteins started to elute separately. The other conditions used like incubation time on ice, concentration, sample volume showed almost the same results. The comparative elution pattern of mixture of concentrated fractions of blood serum proteins with and without $\mathrm{A} \beta$ oligomers is shown in fig. 4. According to this experimental hypothesis if proteins would bind with $A \beta$ oligomers then the bound molecules were supposed to elute together. However, all of the corresponding fractions (fractions containing higher molecular weight) were analyzed on SDS-PAGE. In the gel bands of only $A \beta$ oligomers or only of blood serum proteins appeared which indicated that $\mathrm{A} \beta$ oligomers and blood serum proteins were not interacted strongly (fig.5)

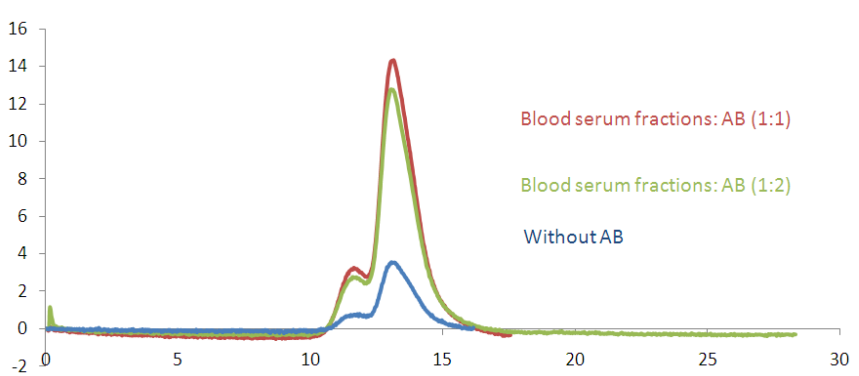

Fig. 4: Chromatogram showing the elution pattern of mixtures of concentrated blood serum fractions and $\mathrm{A} \beta$ oligomers and only blood serum fractions without $\mathrm{A} \beta$.

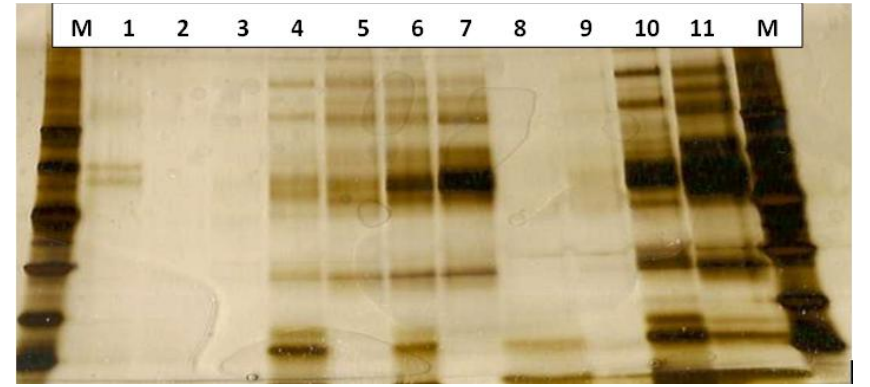

Fig. 5: SDS-PAGE image of concentrated blood serum fractions with $A \beta$, without $\mathrm{A} \beta$ and only $\mathrm{A} \beta$ fractions. Samples loaded as the following order (from left to right): M: Marker (LMW),1: only A $\beta$ fraction, 2: blood serum protein fractions (with $A \beta$ ), 3: without $A \beta$, 4: With $A \beta$, 5: without $A \beta, 6$ : With $A \beta$ (concentrated blood serum fractions), 7: without $A \beta$ (concentrated blood serum fractions), 8: only $A \beta$ fraction, 9: With $A \beta, 10$ and 11: only blood serum fractions (concentrated). From gel image it was observed that bands of only either $\mathrm{A} \beta$ oligomers or blood serum proteins were appeared but no strong bands of interacted molecules were appeared.

\section{CONCLUSIONS}

Size exclusion chromatography is an excellent technique to separate the molecules according to their sizes. Several biologically important molecules or other chemically synthesized molecules can be mixed with $\mathrm{A} \beta$ oligomers and SEC based chromatographic study can be applied to find the binding ligands. If the molecules interacted then it could be further analyzed by Mass spectrometry. In this experiment chromatographic conditions were optimized for better separation of $A \beta$ oligomers and blood plasma proteins. In future $A \beta$ oligomers can be further analyzed using these experimental conditions for several drug discovery efforts.

\section{REFERENCES}

1. Hardy J, Selkoe DJ. The amyloid hypothesis of Alzheimer's disease: progress and problems on the road to therapeutics. Science. 2002; 297:353-356. 
2. Cleary JP1, Walsh DM, Hofmeister JJ, Shankar GM, Kuskowski MA, Selkoe DJ, Ashe KH. Natural oligomers of the amyloid-beta protein specifically disrupt cognitive function. Nat. Neurosci. 2005; 8: 79-84.

3. Glenner GG, Wong CW. Alzheimer's disease: Initial report of the purification and characterization of a novel cerebrovascular amyloid protein. Biochem Biophys Res Commun. 1984; 120:885-890.

4. Selkoe DJ. Alzheimer's disease results from the cerebral accumulation and cytotoxicity of amyloid $\beta$-protein. J Alzheimers Dis. 2001; 3:75-80.

5. Walsh DM, Selkoe DJ. A $\beta$ oligomers - a decade of discovery. J Neurochem. 2007; 101:1172-1184.

6. Roychaudhuri R, Yang M, Hoshi MM, Teplow DB. Amyloid $\beta$ protein assembly and Alzheimer disease. J Biol Chem. 2009; 284:4749-4753

7. Ondrejcak T, Klyubin I, Hu N-W, Barry AE, Cullen WK, Rowan MJ. Alzheimer's disease amyloid $\beta$-protein and synaptic function. Neuromol Med. 2010; 12:13-26.

8. Sakono M, Zako T. Amyloid oligomers: formation and toxicity of A $\beta$ oligomers. FEBS J. 2010; 277:1348-1358.

9. Ferreira ST, Klein WL. The A $\beta$ oligomer hypothesis for synapse failure and memory loss in Alzheimer's disease. Neurobiol Learn Mem. 2011; 96:529-543.

10. Benilova I, Karran E, De Strooper B. The toxic A $\beta$ oligomer and Alzheimer's disease: an emperor in need of clothes. Nat Neurosci. 2012; 15:349-357.

11. Hayden EY, Teplow DB. Amyloid $\beta$-protein oligomers and Alzheimer's disease. Alzheimers Res Ther. 2013; 5:60.

12. Roth M, Tomlinson BE, Blessed G. Correlation between scores for dementia and counts of 'senile plaques' in cerebral grey matter of elderly subjects. Nature. 1966; 209:109-110.

13. BurtisCA, and Ashwood ER. Tietz Fundamentals of Clinical Chemistry, $5^{\text {th }}$ edition; W.B. Saunders company, Philadeslphia,PA. 2001.

14. Turner MW and Hulme B. The Plasma Proteins: An Introduction. Pitman Medical \& Scientific Publishing Co. Ltd., London.1970.

15. Schrader $M$ and Schulz-Knappe P. Peptidomics technologies for human body fluids. Trends Biotechnol. 2001; 19: S55-S60.

16. Kennedy S. Proteomic profiling from human samples: the body fluid alternative; Toxicol. Lett. 2001; 120: 379-884.

17. Wrotnowski C. The future of plasma proteins. Genet. Eng. News. 1998;18: 14 .
18. Adkins JN, Varnum SM, Auberry KJ, Moore RJ, Angell NH; Smith RD, Springer DL, Pounds JG. Toward a human blood serum proteome: analysis by multi-dimensional separation coupled with mass spectrometry. Mol Cell Proteomics. 2002; 1: 947-955.

19. Zhang R, Barker L, Pinchev D, Marshall J, Rasamoelisolo. M Smith. C, Kupchak P, Kireeva I, Ingratta L, Jackowski G. Mining biomarkers in human sera using proteomic tools. Proteomics. 2004; 4: 244-256.

20. Anderson NL, Anderson NG. The human plasma proteome: history, character and diagnostic prospects. Mol Cell Proteomics. 2002; 1: 845-867.

21. Pieper R, Gatlin CL, Makusky AJ, Russo PS, Schatz CR, Miller SS, Su Q, McGrath AM, Estock MA, Parmar PP, Zhao M, Huang ST, Zhou J, Wang F, Esquer-Blasco R, Anderson NL, Taylor J, Steiner S. The human serum proteome: display of nearly 3700 chromatographically separated protein spots on two-dimensional electrophoresis gels and identification of 325 distinct proteins. Proteomics.2003; 3: 1345-1364.

22. Macao B, Hoyer W, Sandberg A, Brorsson A-C, Dobson CM, Hard T. Recombinant amyloid beta-peptide production by coexpression with an affibody ligand. BMC Biotechnol. 2008; 8:82.

23. Merril CR. Silver staining of proteins and DNA. Nature. 1990; 343 (6260): 779-80

\section{How to cite this article:}

Anuj Kumer Das. A Chromatography based interaction analysis of two important biomolecules: neurotoxic Amyloid beta oligomers and human blood plasma proteins. J App Biol Biotech. 2015; 3 (05): 040-043. DOI: 10.7324/JABB.2015.3508 